\title{
EXAMPLE BUILDING DAMAGE CAUSED BY MINING EXPLOITATION IN DISTURBED ROCK MASS
}

\author{
LUCYNA FLORKOWSKA \\ The Strata Mechanics Research Institute of the Polish Academy of Sciences, \\ ul. W. Reymonta 27, 30-059 Kraków, Poland.
}

\begin{abstract}
Issues concerning protection of buildings against the impact of underground coal mining pose significant scientific and engineering challenges. In Poland, where mining is a potent and prominent industry assuring domestic energy security, regions within reach of mining influences are plenty. Moreover, due to their industrial character they are also densely built-up areas. Because minerals have been extracted on an industrial scale in majority of those areas for many years, the rock mass structure has been significantly disturbed. Hence, exploitation of successive layers of multi-seam deposits might cause considerable damage - both in terms of surface and existing infrastructure networks. In the light of those facts, the means of mining and building prevention have to be improved on a regular basis. Moreover, they have to be underpinned by reliable analyses holistically capturing the comprehensive picture of the mining, geotechnical and constructional situation of structures. Scientific research conducted based on observations and measurements of mining-induced strain in buildings is deployed to do just that.

Presented in this paper examples of damage sustained by buildings armed with protection against mining influences give an account of impact the mining exploitation in disturbed rock mass can have. This paper is based on analyses of mining damage to church and Nursing Home owned by Evangelical Augsburg Parish in Bytom-Miechowice. Neighbouring buildings differ in the date they were built, construction, building technology, geometry of the building body and fitted protection against mining damage. Both the buildings, however, have sustained lately significant deformation and damage caused by repeated mining exploitation.

Selected damage has been discussed hereunder. The structures have been characterised, their current situation and mining history have been outlined, which have taken their toll on character and magnitude of damage. Description has been supplemented with photographic documentation.
\end{abstract}

\section{INTRODUCTION}

Underground coal mining distorts original equilibrium of rock mass and causes its natural structure to decay. Due to extraction of mineral deposits running in many seams, and high-thickness seams, mining of successive deposit beds takes place in disturbed rock mass. The consequences are obviously disadvantageous and difficult to forecast. Unfortunately, nearly all coal mining regions in Poland have to contend with this situation [3], [4]. In the area of the Upper Silesian Coal Basin - main coal mining regions in the country - the history of said mineral extraction stretches for almost 200 years. It fuelled transformation of natural land relief and hydrographic conditions. Surface subsidence registered by geodetic measurements (taken over the last 50 years) averages over a dozen to twenty metres, locally reaching as much as thirty metres. 
There are numerous undercuts and overflow land, overburden drainage, the mine waste dumps form [16]. Those transformations take their toll on land development and infrastructure, which have been exposed over many years to time-varying mining influences [17]. Repeated influences change soil structure, which is foundation soil for buildings and cause additional loads on structures.

\section{MINING INFLUENCES ON BUILDINGS}

Underground mining influences affect buildings through subsoil deformation. Said deformation, both in form of displacements and strain impacts foundation penetrating the ground, thus originates additional stress, which via foundation is transmitted onto the buildings' supporting structure. Measures used to describe mining influences use mathematical description of mining-induced surface deformation. The Budryk-Knothe theory is commonly used in Poland to describe surface deformation, where fundamental equations give relations between subsidence of point located on a surface and location of longwall face and time [9], [11], [12]. The Gauss error function is an expression of that relation in geometrical space, whereas as a function of time is exponential.

By assuming definitions of slope and curvature as appropriate derivatives of subsidence functions and that horizontal displacements are proportional to slopes, distribution and intensity can be determined of: horizontal displacements, linear horizontal strain, slope and curvature, which are referred to as deformation indexes. Three of those indicators: slope, radius of curvature and linear horizontal strain have been acknowledged as fundamental measures describing impact of underground mining exploitation on the surface. Figure 1 illustrates distribution of deformation indexes above the edge of mining panel shaped as a half-plane. Distribution and value of exploration indexes are to do with the positioning of longwall face relative to analysed structure and as mining progresses they change. Hence, theoretically when a structure is located beyond the so called radius of influence propagation $R$ with the centre at th longwall face, it should be exposed to permanent loads and time-varying influences. On the other hand, strain, horizontal displacements, slope and curvature should fade out. Then again, structures within the distance $R$ from the longwall edge, should remain in the zone of permanent deformation.

In practice, it is observed that the inflection point of the basin profile is shifted towards the exploited part of the coal seam (goaf). The size of this displacement $p$ is usually defined as a function of the depth of exploitation $H$. In Poland, it is usually assumed that $p=H^{1 / 2}[10]$. Other researchers estimate that the value of $p$ is about 0.1 to $0.2 H$ [1], [7].

When mining operations progress onto successive deposit beds, their impact overlaps with pre-existing deformation and damage to the rock mass. If several or over 
a dozen beds are involved, the foundation soil can become penetrated with complicated, difficult to characterise deformation states [3].

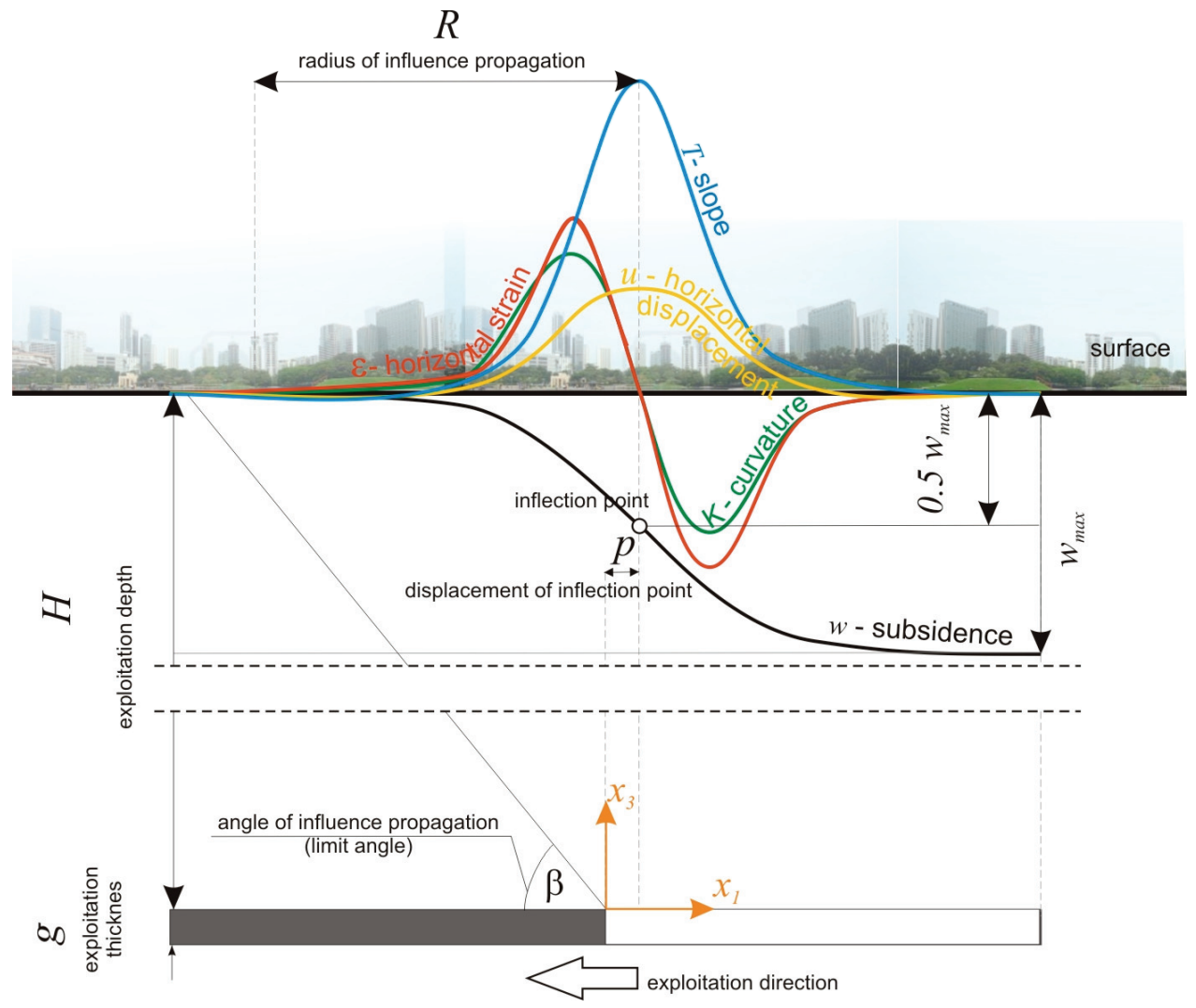

Fig. 1. Distribution of surface deformation indicators above the longwall's edge

Protecting both the terrain and land development against underground mining induced damage involves a two-faceted approach. Means of both mining prevention and building prevention are employed [14]. Mining prevention spells out how to design mining operations to minimise ensuing surface deformation. Building prevention involves designing and constructing various protections - ranging from elements of supporting structures to measures counteracting surface deformation - which allow the structure to safely withstand mining influences. In order for preventative measures to function as intended, the intensity and time-space distribution of mining influences have to be reliably forecasted. Crucial to do so, is factoring in disturbances to the rock mass caused by previous exploration work [4]. Important elements of preventative measures are technical supervision, correct assessment of subsoil and structural condition, monitoring mining-induced changes [5], [6], [13]. The examples which have 
been presented in this paper prove that areas affected by influences of repeated underground mining can develop deformations produced by extraction of successive deposit beds, which are a serious threat to nearby buildings.

\section{LOCATION AND CHARACTERISTICS OF STRUCTURES DISCUSSED}

This paper discusses mining damage sustained by two neighbouring buildings owned by Evangelical Augsburg Parish in Miechowice, namely: the church built in 1896 and the "Mainstay of Peace" Nursing Home built in 1990-1995. Those buildings are located in East end of Bytom, Mother Eve St. (Fig. 2). They are the remaining part of historical building complex dating back to the 19th century. The structures part of the complex were owned by the assembly "Mainstay of Peace" (Friendshort). Most of the buildings were torn down owing both to the II World War and mining damage. Five out of twenty structures stood strong, which went on to create a historical complex, composed by:

- the church,

- so called old rectory, Historicism building erected in 1894,

- old Nursing Home built at the end of the 19th century, in simplified Historicism style blended with Neo-Gothic,

- Mother Eve's House, built at the turn of the 19th and 20th centuries,

- Public Orphanage ("Silence of Zion") erected in Neo-Gothic style.

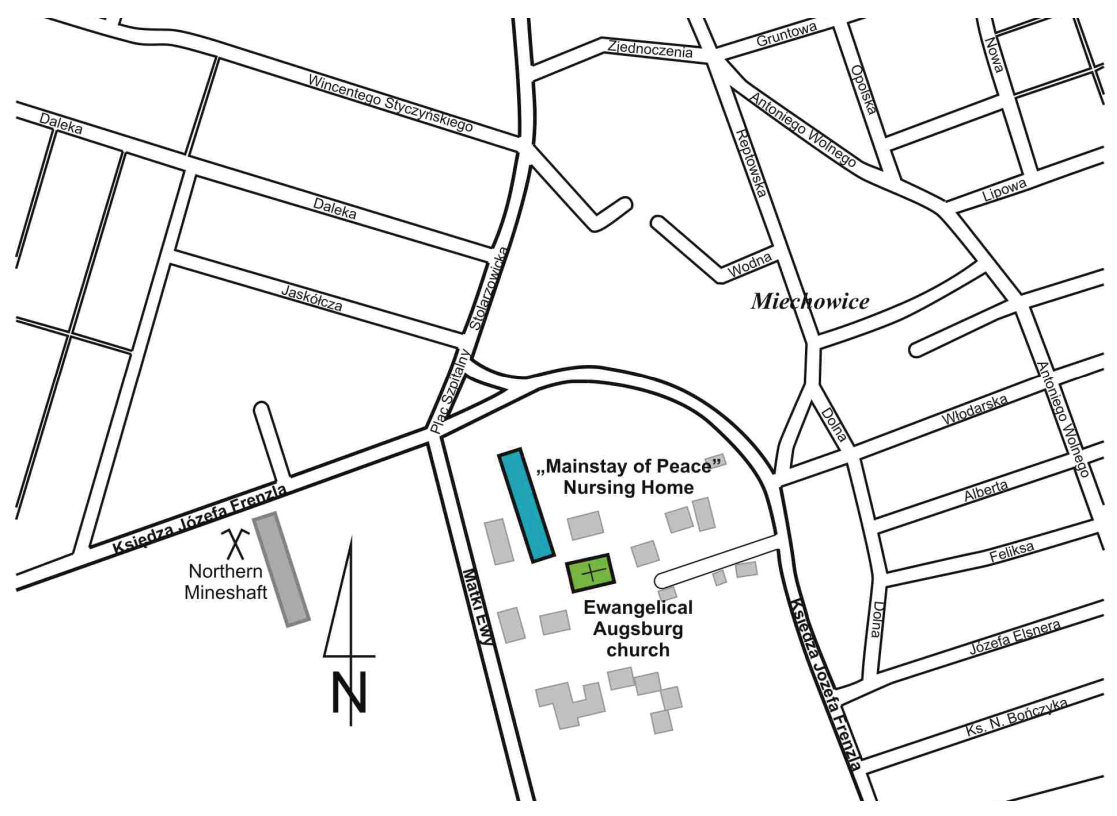

Fig. 2. Location of structures in question 


\subsection{CHARACTERISTICS OF THE CHURCH BUILDING}

The small Neo-Gothic church was built in 1896 (Fig. 3). It is a brick, two-bay structure with some basement area. The aisle is situated northward. The horizontal projection is approx. $20 \times 12 \mathrm{~m}$. Typical of sacred architecture of that period supporting structure features pillars, buttresses, bearing walls and spanning over naves cross-rib vaults. Over presbytery - lierne vault. Northward, next to the aisle, is a quadrilateral tower. In 1987, the entire complex was enlisted in the heritage registers under identification number $\mathrm{A} / 1350 / 87$.

The church was installed with a system of tie-beams and reinforced concrete slab so-called Ledwon slab - to protect it against continuous mining-induced strains. Those protections were put in place separately in time, in response to structural damage and were supposed to prevent further mining-induced damage.

The system of tie-beams comprises: RC tie-beams, $60 \mathrm{~cm}$ below ground level, external steel tie-beams, $40 \mathrm{~cm}$ below parapets (mounted into wall chases) and presented in Fig. 3 and 4 steel tie-beams inside the church, in level with pillars' capitals. Steel tie-beams holding the structure from outside are circumferential (apart from lowinstalled fragments each side of presbytery housing the vestry) and anchored in the walls. Additional transverse anchoring is provided by steel tie-beam separating main nave from presbytery. The steeple is protected by steel anchor in Western wall and steel stretcher in Northern wall.
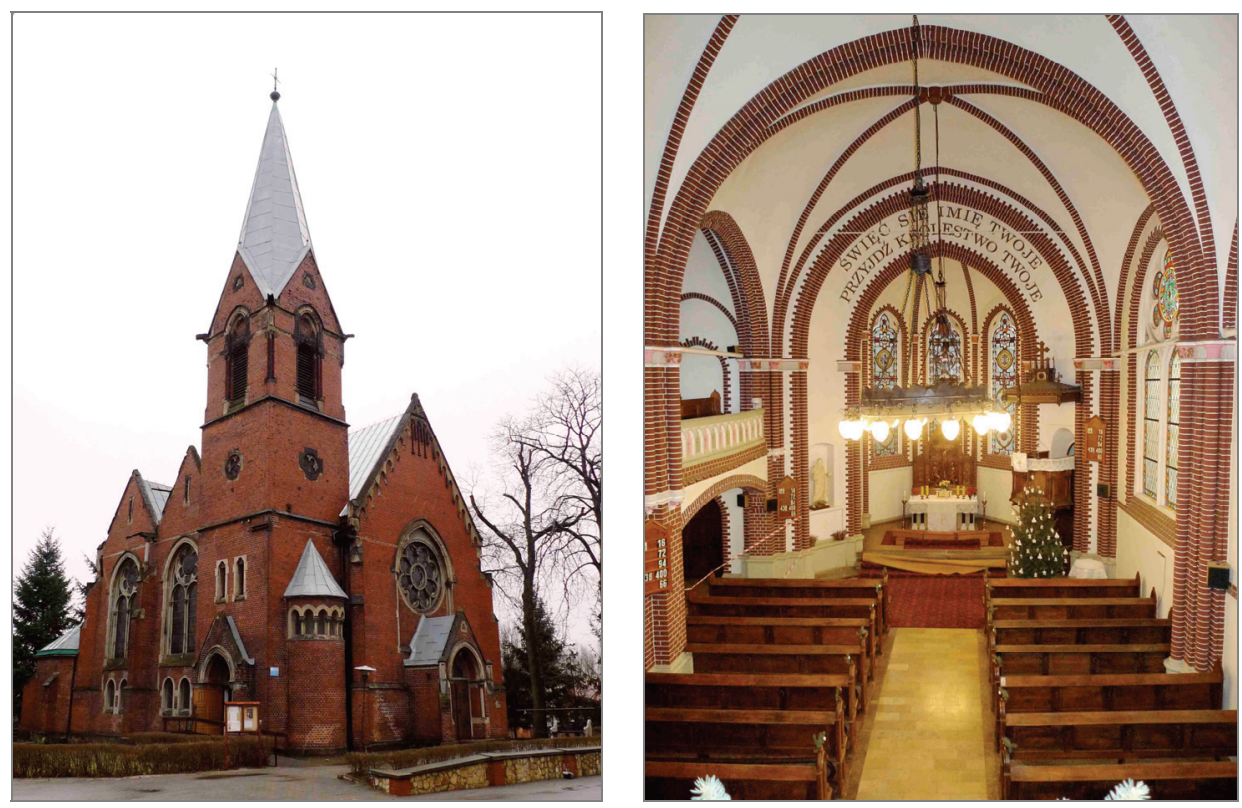

Fig. 3. Evangelical Augsburg Church in Miechowice - views and interior 

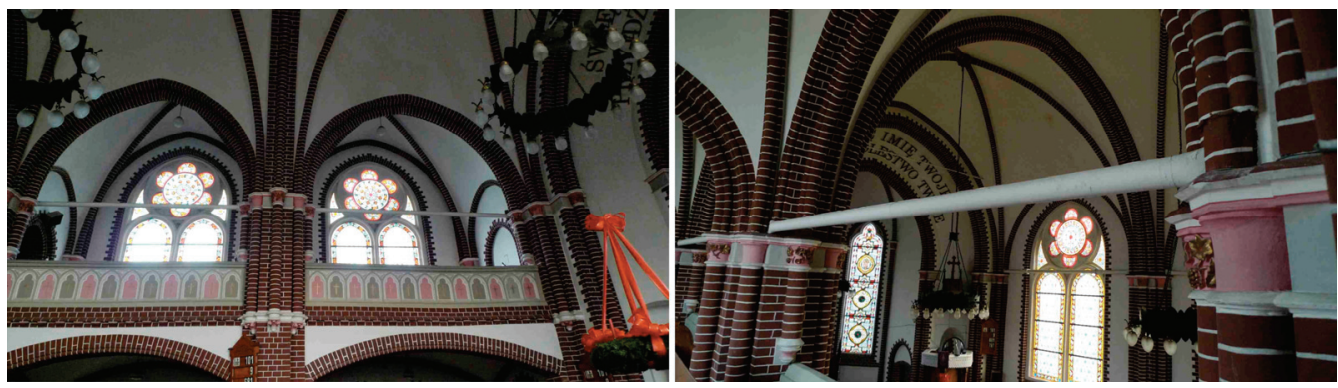

Fig. 4. Steel tie-beams protecting against mining damage

Reinforced concrete slab surrounding the church was made in the mid-1980's. It was put in place as protection against continuous surface deformation caused by mining exploration, especially against horizontal strains. This method was developed by J.A. Ledwon and involves surrounding a building with a RC cross-reinforced slab laid in baseline level [15], [8]. The slab is strengthened with reinforced rib connected with building walls at contact points with the footing.

\subsection{CHARACTERISTICS OF THE NURSING HOME BUILDING}

The building named "Mainstay of Peace" was erected in 1990-1995 (Fig. 5). It was adapted for a Nursing Home for 62 elderly persons. The body of the building was significantly extended - its projection is approx. $77 \times 14 \mathrm{~m}$.

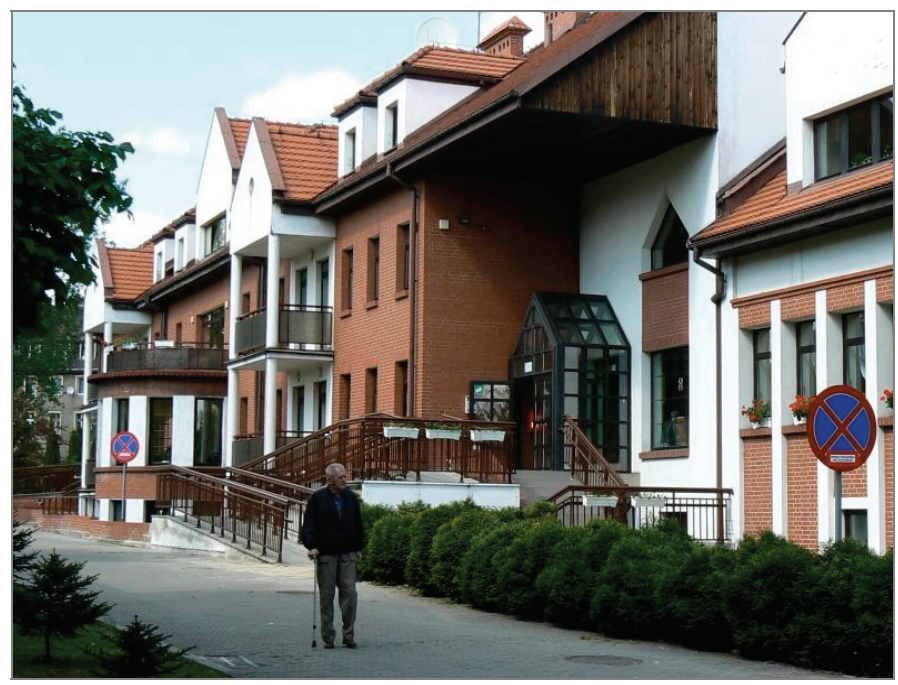

Fig. 5. "Mainstay of Peace" Nursing Home in Bytom-Miechowice 
Due to predicted mining influences the structure was divided into five segments: A, B, C, D and E. Individual segments were separated by expansion joints with design width of $20 \mathrm{~cm}$. The building has basement under the entire ground floor and foundation level approx. $3 \mathrm{~m}$ below ground level. Only lift shaft foundation (segment A) is seated $5.5 \mathrm{~m}$ deep. Each of the segments is protected against mining exploration (parameters of IV category mining area due to continuous surface deformation) with rigid foundation pit. The pit was constructed using:

- RC foundation slab $40 \mathrm{~cm}$ thick, resting on $10 \mathrm{~cm}$ thick concrete footing and separated with an insulation layer made of tar paper,

- RC, monolith basement walls $30 \mathrm{~cm}$ thick,

- monolith, cross-reinforced RC roofs with cribs.

Foundation slabs of neighbouring segments rest on joint combined footing with $140 \times 40 \mathrm{~cm}$ cross-section.

Bearing walls of superstructure were designed as:

- composite walls, load bearing masonry built using cement mortar and brick, 25 $\mathrm{cm}$ thick - exterior gable walls,

- masonry walls built using cement mortar and ceramic brick, $25 \mathrm{~cm}$ thick - interior walls.

Roofs of superstructure is Akerman type beam and block flooring, $24 \mathrm{~cm}$ high with reinforced walling crib. Staircases - monolith, RC; RC headers.

\section{MINING SITUATION AND HISTORY}

The history of mining on an industrial scale in the region of Miechowice dates back almost 190 years. The very first facility mining there on such a vast scale, was the "Maria" ("Maria Grube").

In 1902, the first colliery was opened, called "Prusy" ("Preussen Grube"), part of the Miechowice United Mine (Consolidierte Miechowitzer Steinkohlengrube), owned by Hubert von Thiele Winckler. Since 1945 that mine continued operation rebranded as KWK "Miechowice", and since its merger (in 1997) with KWK "Bobrek", as KWK "Bobrek-Miechowice". In 1991, the "Bobrek-Miechowice" mine went into administration. After liquidation a new entity emerged - Bytom III Mining Company.

Figure 6 illustrates location of "Mainstay of Peace" and facilities part of "Maria", "Prusy" and "Fryderyk" mines, drawn up based on German map of Bytom (Messtischblatt, Beuthen 3309), made in 1907.

The buildings in question are currently incorporated into Bytom III - ZG Mining Region and a namesake mining area (AT the Register of Mining Regions). Current concession entitling for extraction of black coal in that area covers the years 19992026. The structures in question are within reach of influences caused by "Ruch Bobrek", which continues mining exploitation previously conducted by the "BobrekMiechowice" mine. The exploration takes place in Mining Protection Areas of Karb 
ce" mine. The exploration takes place in Mining Protection Areas of Karb and Miechowice districts and the railway route Bytom-Tarnowskie Góry.

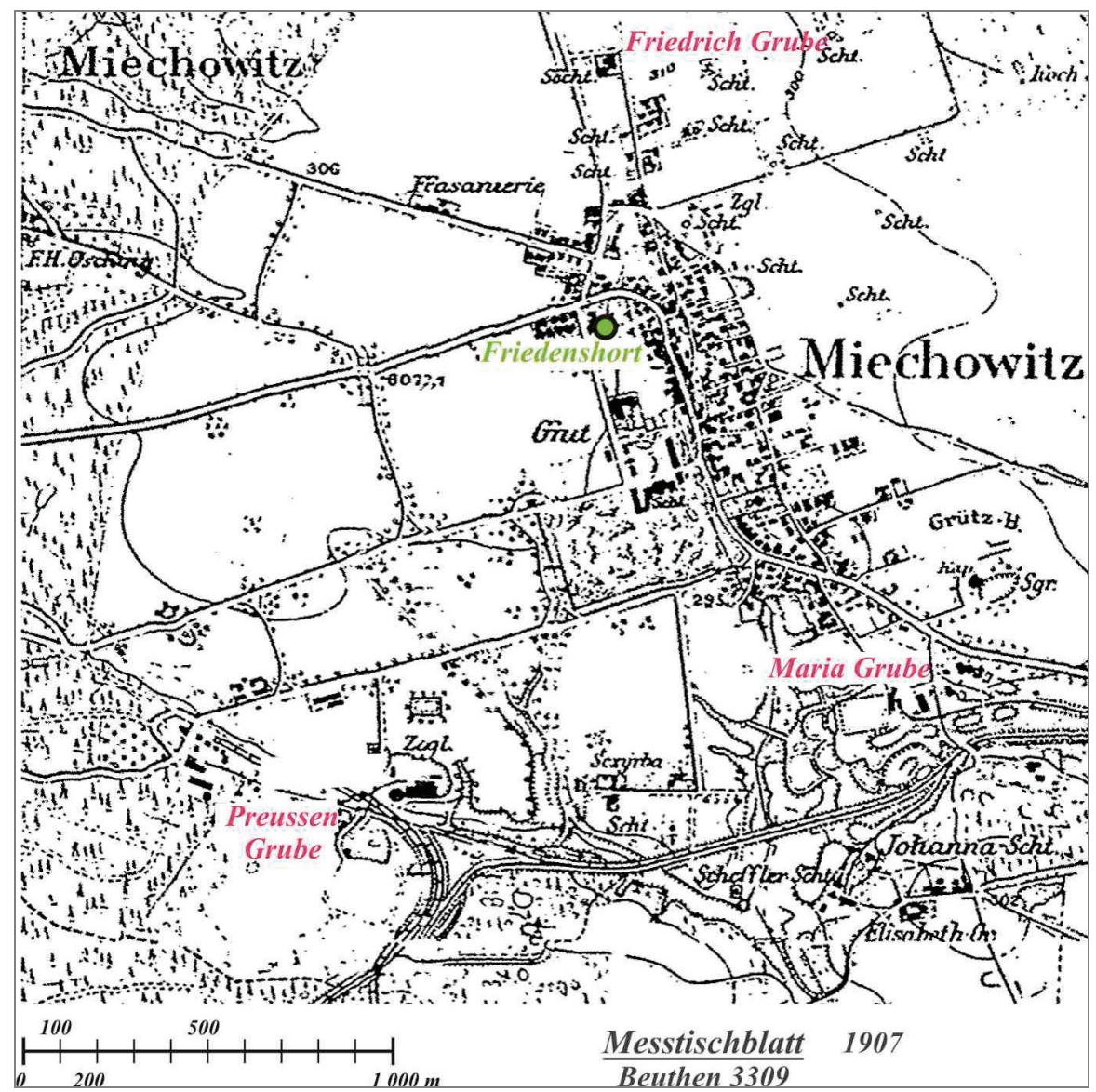

Fig. 6. Location of structures in question relative to the mines

"Maria", "Fryderyk" and "Prusy", based on the map of Bytom, 1907 (Messtischblatt, Beuthen 3309)

Deposits of black coal beneath Miechowice were mined in a total of 13 seams, running both in Ruda Beds (seams 406/4, 414/1-3, 418 and 419) and Saddle Beds (seams 501, 503, 504, 506, 507, 509, and 510). Lately, five seams have been mined in the region of structures in question: 503, 504, 507, 509 and 510. Further mining of 503, 504 and 510 seams is planned for 2012-2014 period. Figure 6 illustrates the outline of longwalls worked out in 2008-2010 and the currently mined 18a longwall. The church and nursing home have also been marked.

As shown in Fig. 7, over the past 5 years directly beneath the building were:

- longwall 72a in seam 507wd (lower layer) - mined in 2008-2009, 
- longwall 97a in seam 509wd (lower layer) - mined in 2009-2010,

- longwall 18a in seam 510wd (lower layer) - mined in 2011-2012.

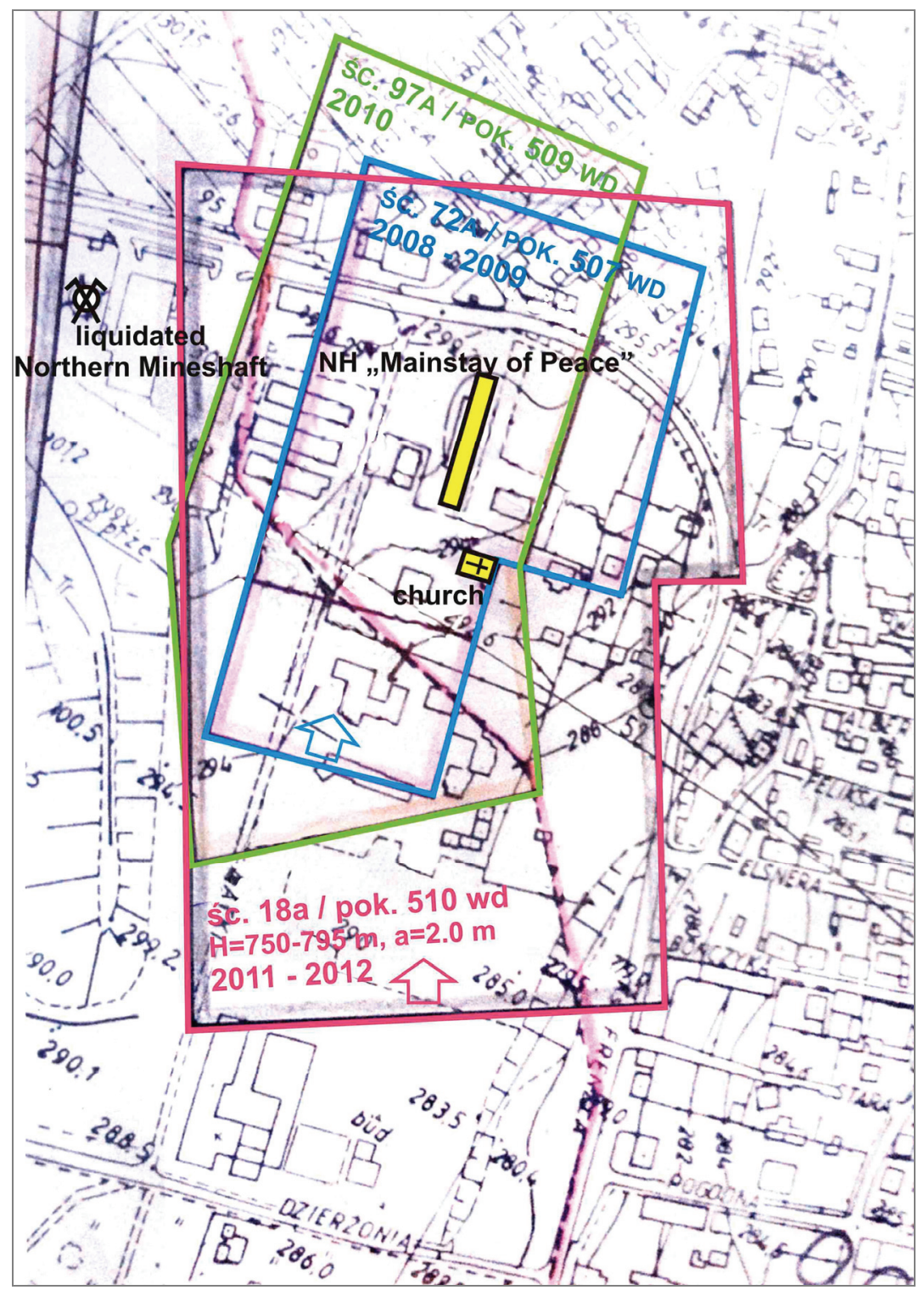

Fig. 7. Location of the structures relative to longwalls mined in 2008-2012

Approximately $220 \mathrm{~m}$ east from the structures in question the closed Northern Mineshaft is located, part of the old "Prusy" mine (Miechowitzschacht der Pressen- 
grube). Currently mining in said region takes place to a large extent in its former Mining Protection Area.

The caving exploitation technique is employed for mining operations in the area in question. The ground support system used has negative impact on surface protection because there is no filling installation. Hence, main measures allowing mining prevention are: limiting wall height and limiting excavation speed.

\section{IMPACT OF MINING EXPLOITATION BEFORE 2011}

Due to the mining-induced disturbances to the rock mass structure in the area of Bytom, the land relief became corrupted. Natural land relief underwent degradation owing to continuous and discontinuous surface subsidence as well as phenomena related to changing hydrographic conditions and tremors. Comparison between topographic maps containing contour lines and ordinates of height shows that between 1914 and 2012 there was an approx. 6-7 m subsidence in the said region. Compared to the general geomorphological change in the area of Upper Silesian Coal Basin (USCB), that is not a particularly large subsidence. Geodetic measurements being taken in that area since 1965 show that in the region of Machowice during the last 46 years, subsidence reached $19 \mathrm{~m}$, whereas local subsidence in Bytom reaches $30 \mathrm{~m}$.
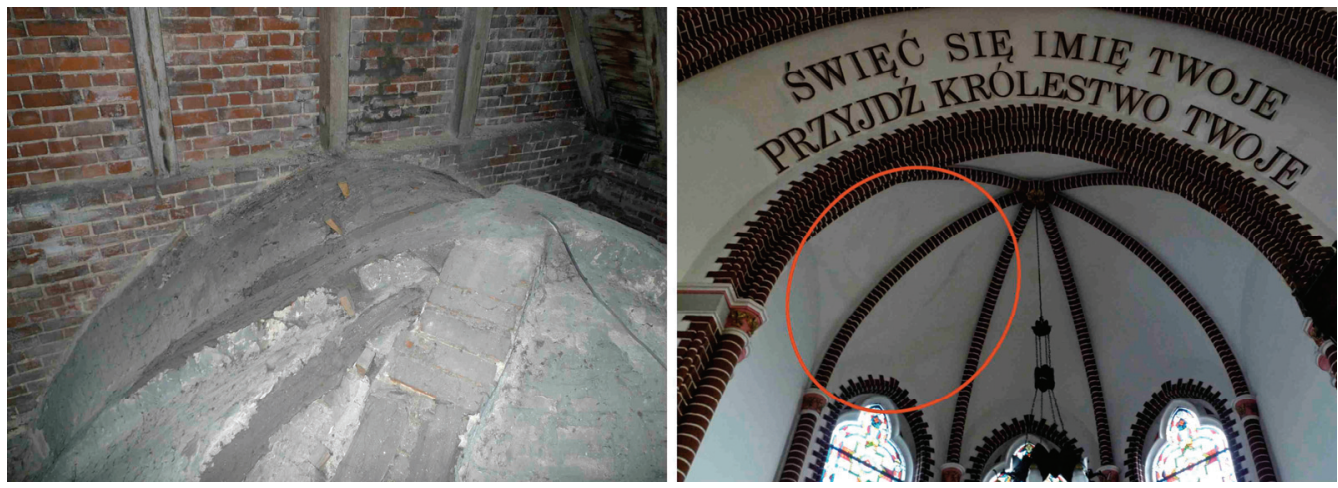

Fig. 8. Repair work done to top and bottom surfaces of vaults

Despite relatively insignificant vertical displacements, the subsoil below structures in question was affected by negative transformations related to horizontal influences. The documentation preserved shows that in the 1960's, caused by those influences were wide-spreading cracks in the load-bearing exterior walls, especially the Northern wall, cracking vaults, arches, choir loft and substantial damage to the floor. Back then, designed and installed were protections and reinforcements for the load-bearing structure, coming as aforementioned circumferential system of anchors situated at two 
levels. Despite repairs and reinforcements fitted to church building, new damage occurred on a regular basis. It was predominantly cracking vaults - repaired several times through wedging and cementation at first. In recent years, epoxy resin packing materials were used (Fig. 8). Cracked walls were also repaired, as was damaged floor. Stained glass windows were replaced - mining damage.

In the 1980's another protection, i.e., the aforementioned RC slab surrounding the building, was installed. This protection also proved insufficient and could not stop progressing damage to the building, caused by excavation of subsequent seams.

Exploration of longwall 72a in seam 507wd and longwall 97a in seam 509wd mined between 2008-2010 meant that the church building was found situated in a particularly unfortunate location, which is illustrated in Fig. 6. Once longwall 72a had been worked out, the building remained in the zone of permanent, positive horizontal strains due to ravelling of mining-area subsoil in convex part of basin's slope $(p \approx 28 \mathrm{~m}$ ). Once longwall 97a had been worked out the church building remained in zone of permanent compressive strains. Those factors substantially disturbed the structure of the subsoil. This was revealed, among others, by deformations of paving stone of road surface in car parks and internal traffic routes. Manhole covers have visibly moved, underground electric network sustained some damage as well.

\section{CONSEQUENCES OF MINING EXPLORATION BETWEEN 2011 AND 2012}

Exploration of longwall 18a in seam 510wd started in 2012, 750-795 m deep. The panel is located in Western part of Mining Protection Area of Miechowice district, in former Mining Protection Area of decommissioned "Northern" mineshaft. Mining exploration went from South to North. The average thickness of excavated strata was $2.0 \mathrm{~m}$. Surface deformation forecasts project that exploration of the 18 a longwall will have caused $0.9 \mathrm{~m}$ subsidence, $1.5 \mathrm{~mm} / \mathrm{m}$ horizontal strains and $3.0 \mathrm{~mm} / \mathrm{m}$ sloping.

\subsection{DAMAGE SUSTAINED BY THE CHURCH}

The church due to repeated mining influences sustained multiple damage, which manifests itself as cracked vaults and walls. In a bid to protect the structure against mining damage, it was fitted with a reinforced concrete slab - a so-called Ledwon slab. Steel tie-beams were also fitted, which fasten together the main nave both longitudinally and transversally. Numerous maintenance repairs and major repairs predominantly involved wedging and gluing together vaults. In recent year epoxy resin fillings have been employed (Fig. 8). Cracked walls were also repaired and stained glass windows were replaced - mining damage. 
the state prior to December 9, 2012 (fot. 02-12-2011 r.)
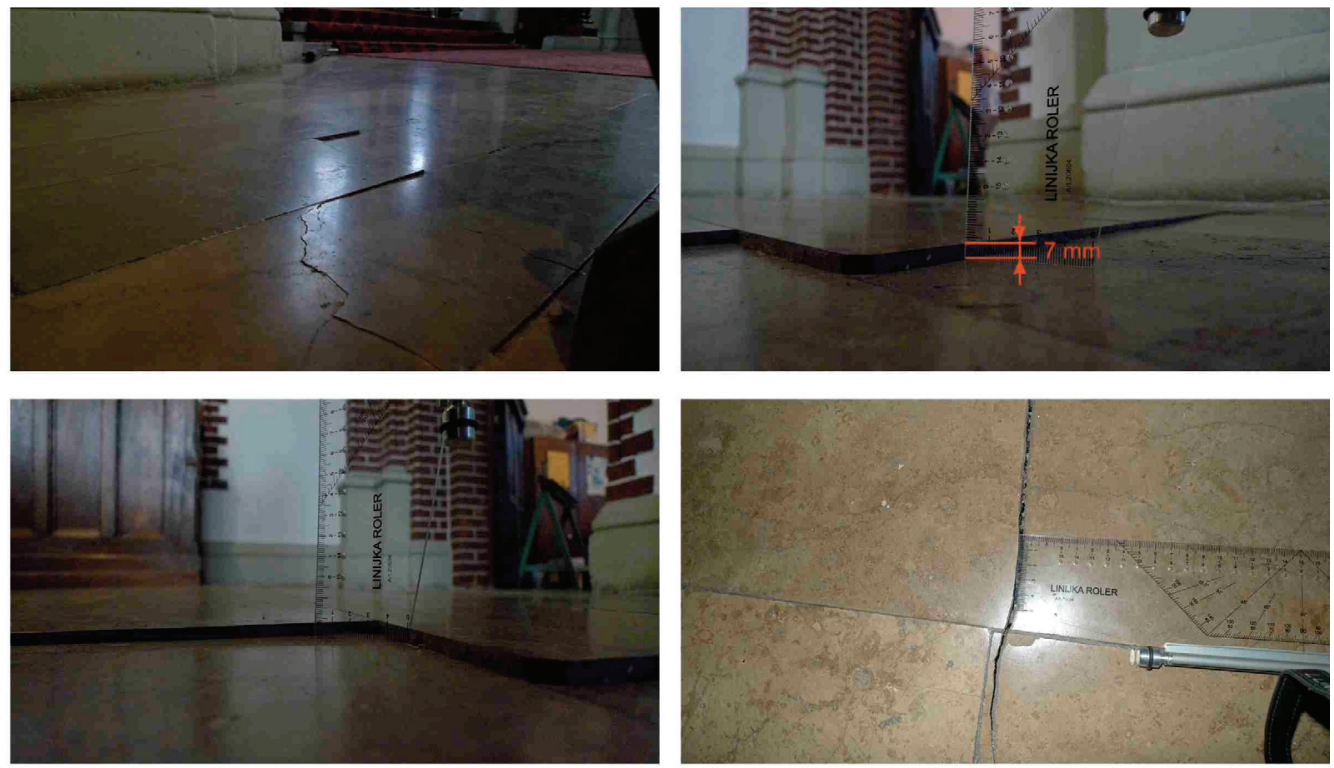

the state after 9 December 2012 (fot. 5-01-2012 r.)
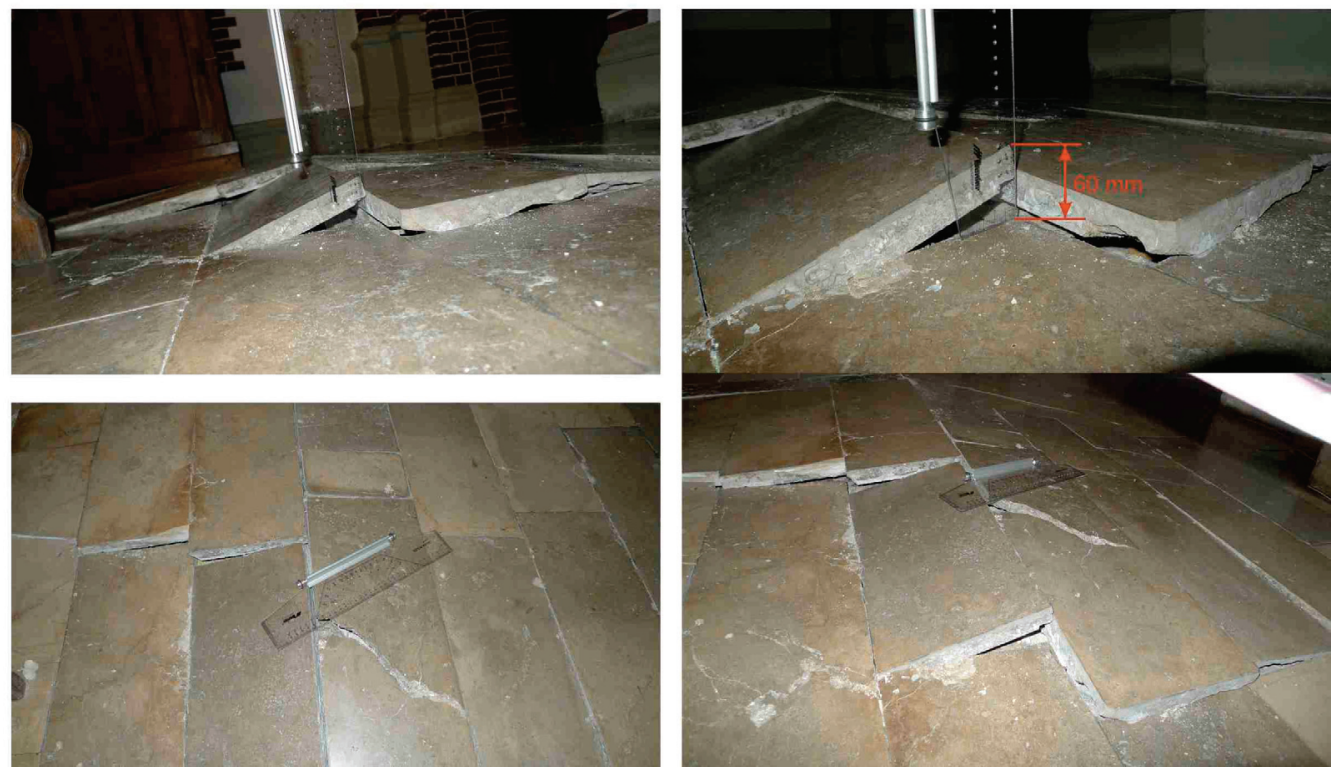

Fig. 9. Damaged church floor 


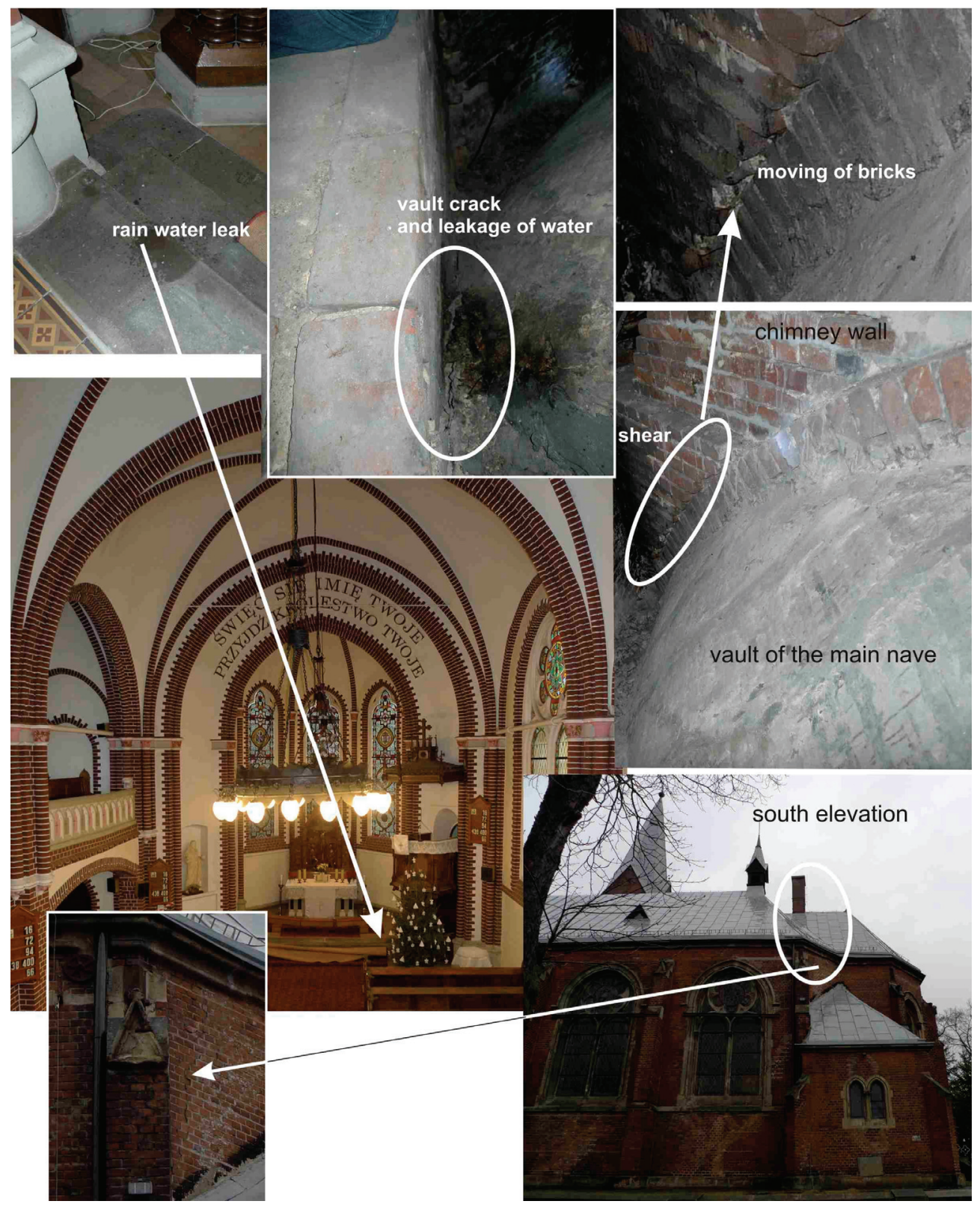

Fig. 10. Damaged vaults and crosswall of the church

Because mining exploitation is still taking place nearby the church, the structure sustains damage on an ongoing basis. Due to excavation of longwall 72a/bed 507wd, the structure became located in the zone of permanent surface deformation. Currently 
the longwall 18a/bed 510wd is being mined, which progresses from South to North. Despite longwall face being beyond the reach of major influences (as on January 2012), both the building and its surrounding show worrying deformation and damage. The church's floor made of stone plates became unevenly deformed. There are considerable floor bulges in the aisle located in the Northern part of the church. Evident were also cracks and vertical displacements of tiles. The condition of the building significantly worsened as of 9 December 2011, when the floor abruptly elevated and shattered with acoustic effects accompanying. Figure 9 illustrates a comparison between the state of the floor from 2 December when property condition was surveyed and its state after the abrupt event.

Cracks in the floor have also surfaced in other parts of the church. The crevice above the alter becomes ever-more evident. The line demarcating change in the slope of church's body also runs through that point. Said line seems "broken" along the wall parting presbytery and main nave. Vast cracks in the vault are also visible there, which lately (about 5 January 2012) increased enough for the rain water to leak in and drip on the altar's steps. This is indicative of sheet metal roof also becoming damaged. Figure 10 illustrates said damage. The stack partition, which is under shear stress becomes alarmingly deformed. The photograph shows major displacement of bricks composing stack partition, both in the loft and exterior wall - Southern elevation.
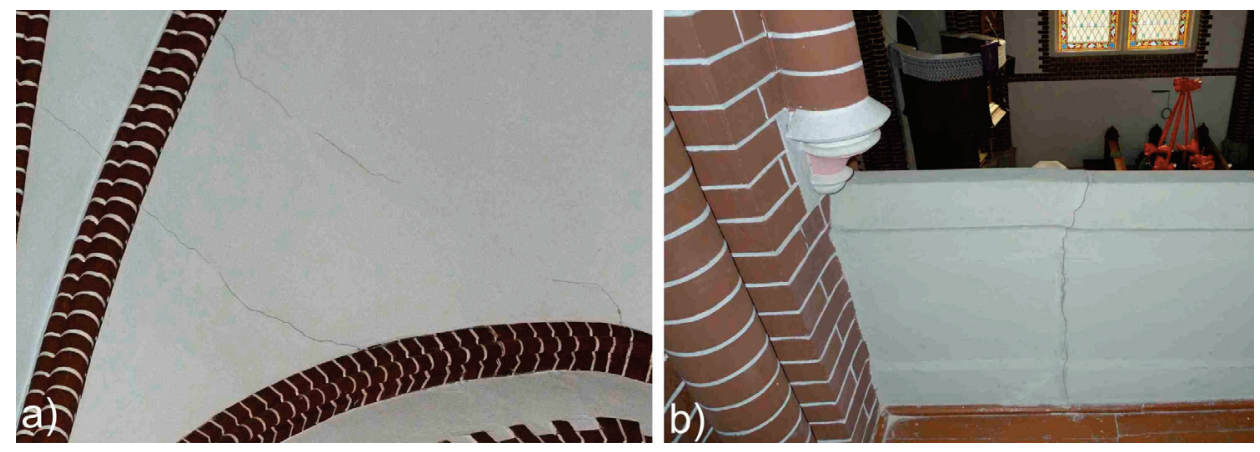

Fig. 11. Damage sustained by the church: (a) cracks in vault above main nave, (b) cracks in choir loft

Apart from the aforementioned, the entire church is riddled with numerous cracks both in church's vaults and walls. Figure 11 illustrates a selection of places, where damage surfaced: main nave's vault cracks and cracks in choir loft's parapet, located in the aisle.

\subsection{DAMAGE SUSTAINED BY THE NURSING HOME}

The Nursing Home building, whose structural designs factored in mining-induced surface deformation of IV category, sustained substantial damage over the past five 
years. Figure 12 shows displacement of small wall's curvature, illustrating surface deformation. Figure 13 illustrates crack in the exterior wall near the South-East corner of the structure.

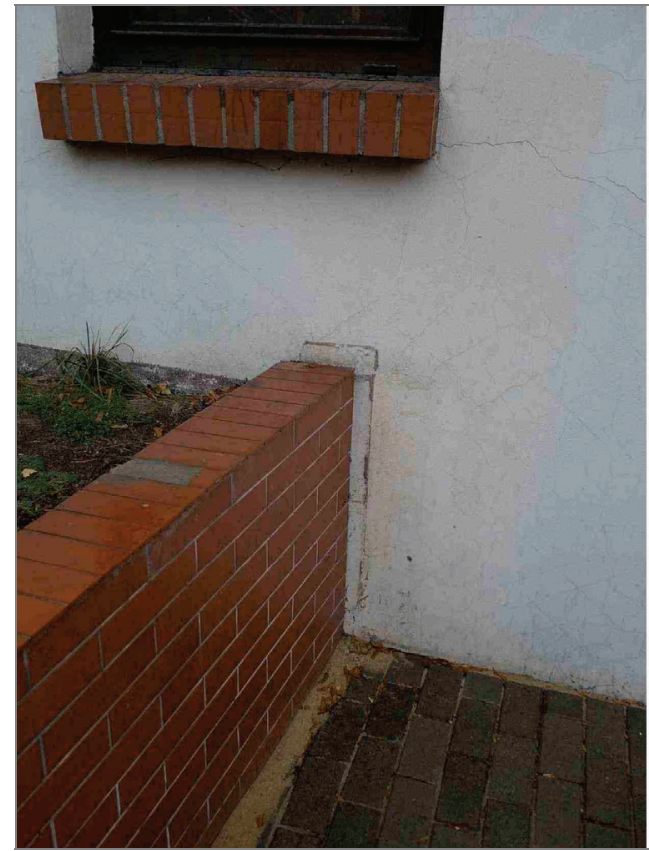

Fig. 12. Displacement of the building illustrated by original location of retaining wall

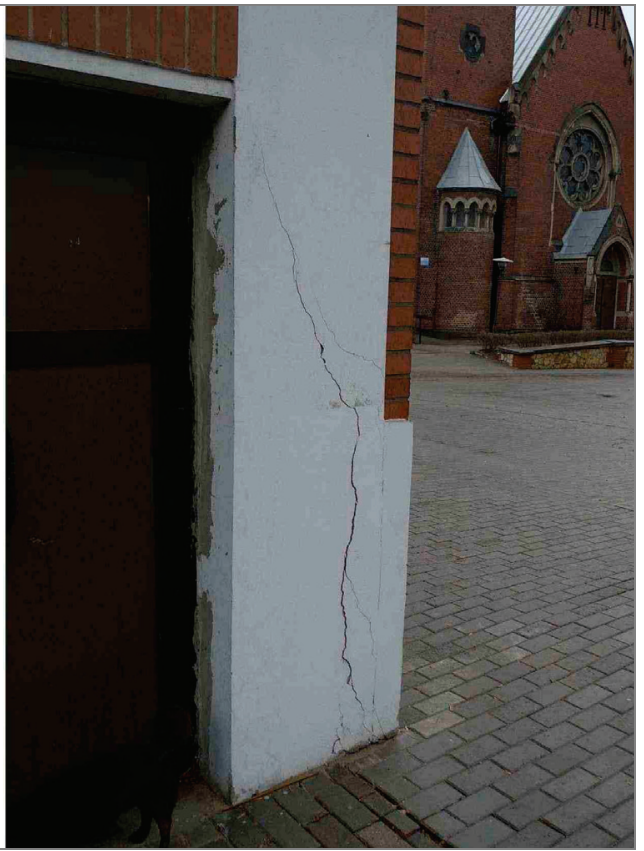

Fig. 13. Cracked wall near South-West corner of the Nursing Home

The tilted body of the building makes it difficult to use it. Moreover, due to specific function of the building, even the slightest ignorable for healthy individuals slope of the floor is spawning issues. According to the measurements that were made in August 2012 the tilt of the building is $1.6 \%$ in the southern part and more than $3 \%$ in the northern part. Significant vertical tilt hampers using the lift (Fig. 14). Substantial cracks in segment joints are visible (Fig. 15). Due to displacements of walls and ceilings, also deformed became sanitary and heating infrastructures. Figure 16 illustrates a pipe indented caused by pressure of wall, which had to be removed to prevent major damage to the installation. Similar situation is illustrated in Fig. 17, where apart from indent pipes and need to wall cutting, deformation of vertical segment of the pipe is shown. 


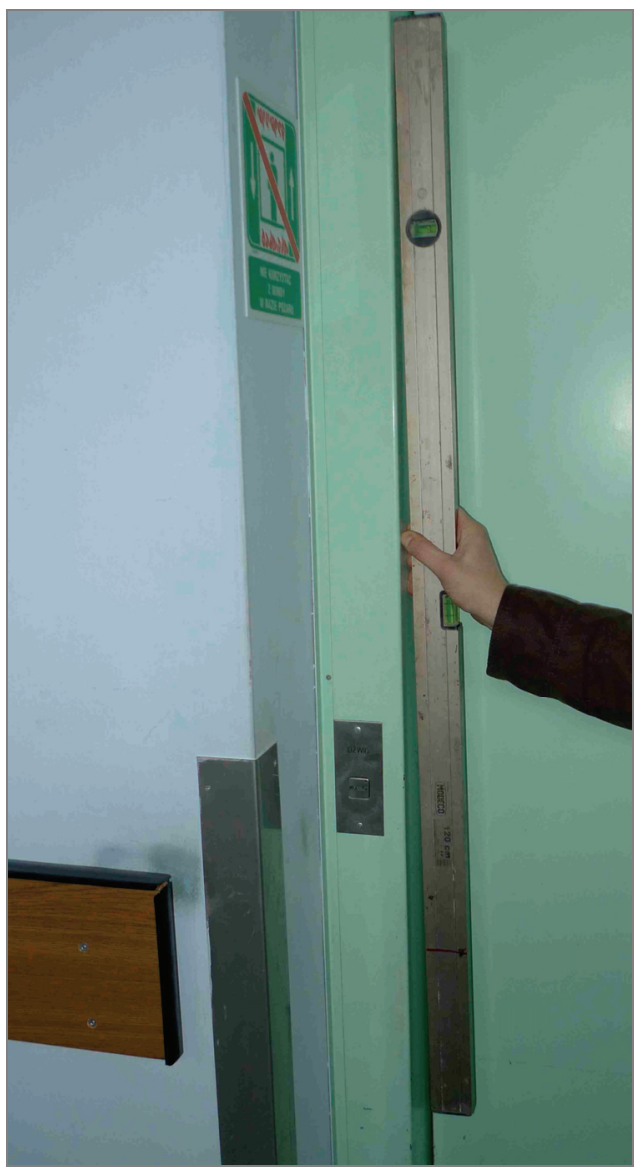

Fig. 14. Vertical tilt of lift shaft

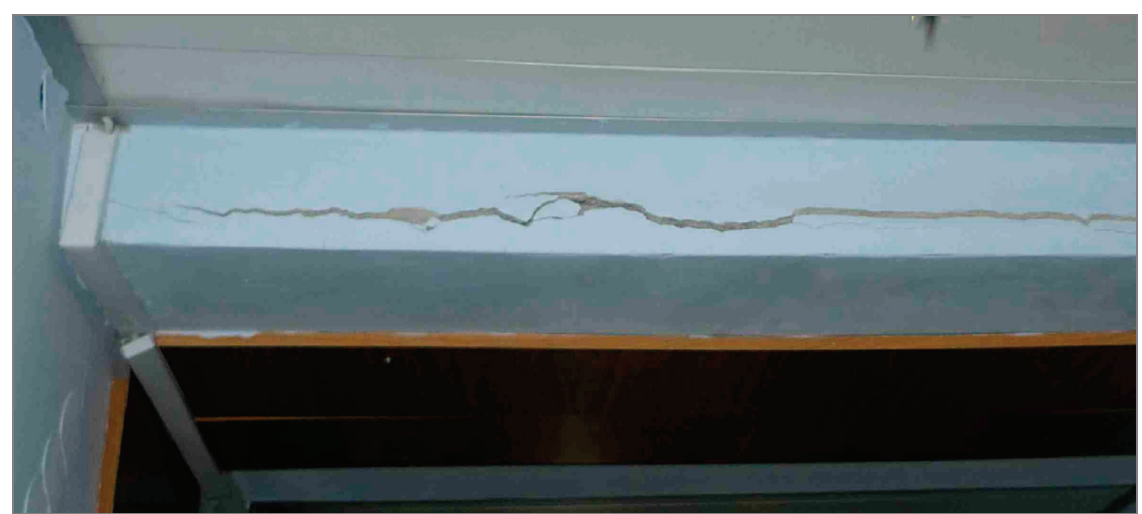

Fig. 15. Crack in places of dilation between building's segments 

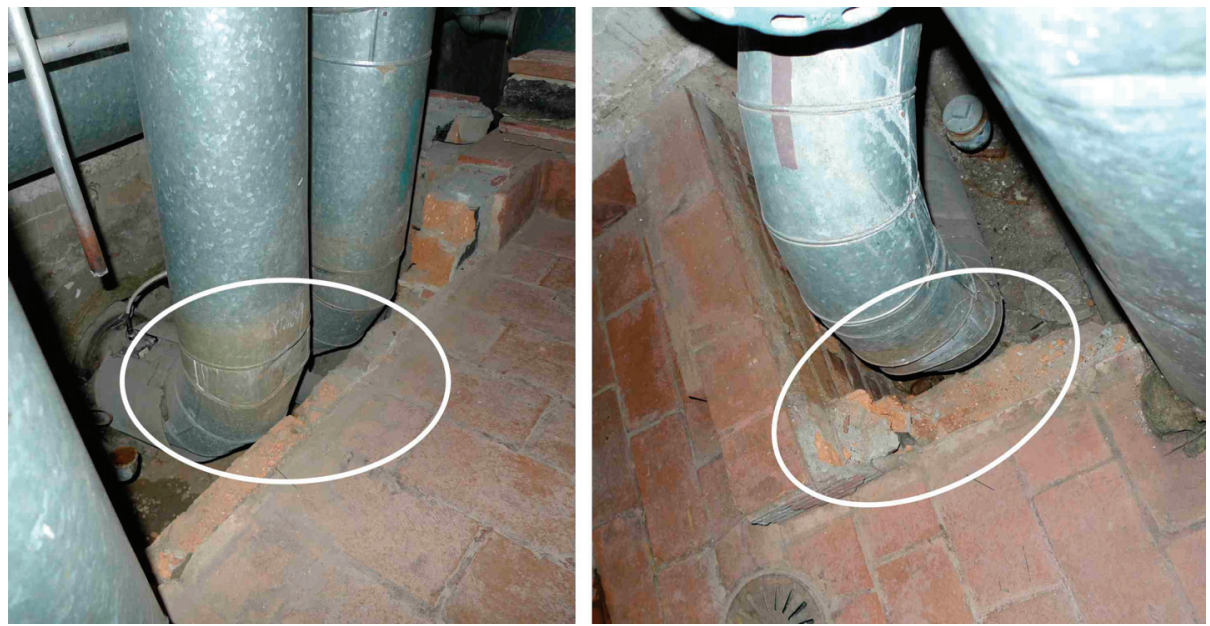

Fig. 16. NH boiler room. Visibly bent pipes and incuts made to protect the piping from damage
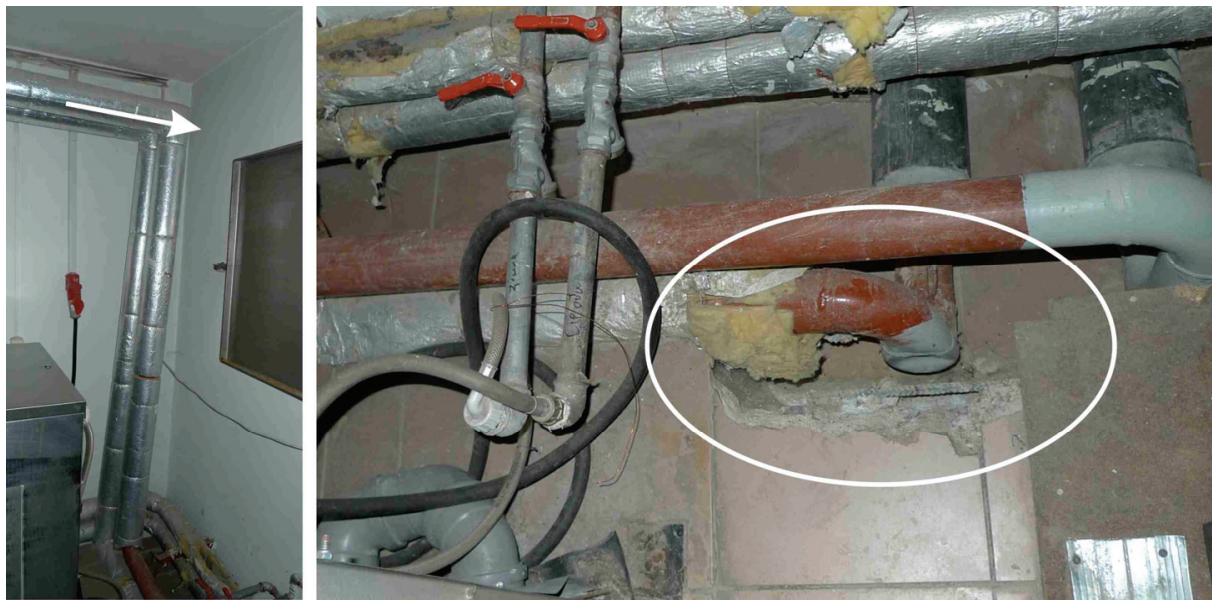

Fig. 17. NH laundry room. Visibly bent pipes and incuts made to protect the piping from damage

Throughout the building visible are also cracks and cracks of walls, ceilings and lintels.

\section{SUMMARY AND CONCLUSIONS}

This paper discussed the issues of negative impact of underground coal mining in disturbed strata on buildings. Mining-induced damage was illustrated with an example

of two structures. Both buildings are founded in the area impacted by repeated mining 
influences. The mining damage which surfaced just lately both at the surface and inside the structures proves that the structure of surface soil layers is substantially disturbed. Deformations of surface, paving stone and floor of the church are a testimony confirming the non-uniform strain of the ground. They are a result of repeated mining exploration and impact of longwalls worked out between 2008 and 2010. The fact that the church building remained within the zone of permanent positive strains after exploration of 72a longwall, and then within zone of permanent negative strains following exploration of 97a longwall was a critical, negative factor. Longwall boundaries intersect near said buildings, which had its considerable influence on worsening geotechnical conditions for both structures.

Both the over a century old church and the 17-year old Nursing Home had been fitted with protection against mining damage. The new building was specifically designed to withstand category IV deformation. In spite of the preventative measures both structures sustained considerable damage, which can be indicative that real surface deformation exceeds the maximum surface deformation permitted for regions acknowledged as building land. Despite employing means of building protection, no mining prevention in place for structures in question caused substantial, recurring and costly to repair damage.

Observations of surface deformation and damage to existing land development located within the USCB area - examples of which have been presented in this paperequivocally prove that mining successive beds of deposits causes ever-more threatening influences. Under those conditions in mining areas properties of subsoil change due to repeated strain - alternately compressive and tensile. The technical condition of building subject to said deformation for decades has to successively deteriorate with time, thus decreasing the structure's resilience to mining influences [2], [3]. Not only do mechanical properties of building materials change, but also joints are exposed to changing states of stress. Furthermore, quite often due to sustained deformation and damage static diagram of the supporting structure also changes. Thus a conclusion arises that there is a need for more restrictive preventative measures.

A forecast of surface deformation has to include disturbances to the rock mass caused by repeated mining operations, mining history of the region and possible activation of old horsts. Hence it is necessary to:

- query mining records concerning mining operations in a given region,

- examine available results of geodetic measurements taken of surface deformation,

- investigate geologic structure, especially in terms of discontinuities, faults, etc.,

- gather data on planned mining operations.

Fundamental for protection against mining damage is drawing up a reliable and competent forecast of structural behaviour under conditions of planned mining operations. Such forecast should include all the above-mentioned factors based on analysis of mining, geotechnical and structural conditions of given structure. 


\section{REFERENCES}

[1] AdAmeK V., Jeran P.W., Evaluation of existing predictive methods for mine subsidence in the U.S. Proceedings of Workshop On Surface Subsidence Due To Underground Mining. Nov. 30-Dec. 2, 1981, Dept. of Mining Engineering College of Mineral and Energy Resources West Virginia University, Morgantown, March 1982, 88-98.

[2] BRYT-NitARSKA I., Factors influencing technical conditions surveying part of research into impact of mining exploitation on building structure, Papers of the Building Research Institute, Year 35, No. 4, 2006, (in Polish).

[3] Florkowska L., Land subsidence due to Mining Operations in Disturbed Rock Mass, on the Example of Ruda Ślaska (Poland), Archives of Mining Sciences, 2010, Vol. 55, 691-701.

[4] Florkowska L., Non-linear numerical mechanics in issues of protecting building located in mining areas, Archives of Mining Sciences, Monograph, No. 11, Cracow 2010, (in Polish).

[5] FlORKOWSKA L., KANCIRUK A., The remote building deformation monitoring system, [in:] A. Kowalski (ed.), Safety and protection of buildings in mining areas, GIG, Katowice, 2012, 53-61, (in Polish).

[6] HoŁa J., Schabowicz K., State-of-the-art non-destructive methods for diagnostic testing of building structures - anticipated development trends, Archives of Civil and Mechanical Engineering, 2010, Vol. X, No. 3, 5-18.

[7] KARMIS K. et al., The potential of the zone area method for mining subsidence prediction in the Appalachian Coalfield, Proceedings of Workshop On Surface Subsidence Due To Underground Mining, Nov. 30-Dec. 2. 1981, Dept. of Mining Engineering College of Mineral and Energy Resources West Virginia University, Morgantown, March 1982, 48-58.

[8] KAWULOK M., Strengthening of traditional church buildings subjected to mining influences, Technical Transactions, Cracow University of Technology, Issue 9, Year 106, 2009, 191-198 (in Polish).

[9] KNOTHE S., Observations of surface movements under influence of mining and their theoretical interpretation, Proceedings of the European Congress on Ground Movement, The University of Leeds, April 9-12th 1957, 210-213.

[10] KNOTHE S., Prediction of mining exploitation influences, Pub. "Śląsk” 1984, p. 12 and p. 122), (in Polish).

[11] KnотHe S., Equation of subsiding trough's curvature, Archives of Mining and Metallurgy, 1953a, Vol. 1, Issue 1, 22-38, (in Polish).

[12] Knothe S.B., Time influence on formation of a subsidence through, Mining and Metallurgy Archives, 1953b, Vol. 1, Issue 1, 128-139 (in Polish).

[13] Koszela J., Koszela-MareK E., Engineering geology and geotechnics in civil engineering, Studia Geotechnica et Mechanica, 2009, Vol. 31, No. 3, 17-23.

[14] KwiateK J. (ed.), Protection of buildings in mining areas, GIG Publishing House, Katowice, 1997, (in Polish).

[15] LEDWoń J.A., Buldings in mining areas, Arkady, Warszawa 1983, (in Polish).

[16] Ecophysiographic documentation for Land Use Planning of the Silesian Voivodeship. Chapter III. Diagnosis of natural environment's state and functioning with preliminary forecast of changes, Katowice 2004, (in Polish).

[17] Stilger-SzydŁo E., TutAJ W., The effect of subterranean exploitation of mines on the state of stress and displacements of transport embankments, Archives of Civil and Mechanical Engineering, 2005, Vol. V, No. 1, 65-90. 